\title{
Prawna ochrona dobrostanu zwierząt gospodarskich podczas ich uboju
}

1. W naszej kulturze ubój zwierząt gospodarskich stanowi nieodzowny element ich wykorzystania - konieczny do pozyskania niektórych produktów pochodzenia zwierzęcego. Mimo że życie zwierząt jest dobrem prawnie chronionym $^{1}$, w art. 6 ust. 1 ustawy o ochronie zwierząt ${ }^{2}$ wprowadzono bowiem zakaz ich zabijania, to ustawodawca przewidział sytuacje, w których uśmiercenie zwierzęcia jest dozwolone po spełnieniu odpowiednich warunków. Należą do nich: ubój i uśmiercenie zwierząt gospodarskich oraz uśmiercanie dzikich ptaków i ssaków utrzymywanych przez człowieka w celu pozyskania mięsa i skór, a także zabicie lub poddanie ubojowi zwierząt gospodarskich $\mathrm{z}$ nakazu powiatowego lekarza weterynarii $\mathrm{w}$ określonych przypadkach. W przypadku zwierząt gospodarskich ochrona życia jest zatem silnie ograniczona przez sposób, w jaki człowiek je wykorzystuje.

Kwestia postępowania ze zwierzętami w momencie ich śmierci znalazła odzwierciedlenie zarówno w aktach prawa międzynarodowego, europejskiego, jak i krajowego. Wśród najważniejszych z nich należy wymienić europejską konwencję o ochronie zwierząt przeznaczonych do uboju ${ }^{3}$, rozporządzenie Rady (WE) nr 1099/2009 w sprawie ochrony zwierząt podczas

* Uniwersytet im. Adama Mickiewicza w Poznaniu.

${ }^{1}$ Szerzej: M. Gabriel-Węglowski, Przestępstwa przeciwko humanitarnej ochronie zwierząt, Toruń 2008 , s. 76 i n.

${ }^{2}$ Ustawa z 21 sierpnia 1997 r. o ochronie zwierząt (t.j. Dz. U. z 2020 r., poz. 638, dalej: u.o.z.).

${ }^{3}$ Europejska konwencja o ochronie zwierząt przeznaczonych do uboju, sporządzona w Strasburgu 10 maja 1979 r. (Dz. U. z 2008 r., Nr 126, poz. 810). 
ich uśmiercania ${ }^{4}$ oraz polską ustawę o ochronie zwierząt. Mimo że sam akt odebrania życia jest formą przemocy i okrucieństwa, to ubój zwierząt gospodarskich rozpatruje się w kontekście ochrony humanitarnej i dobrostanu zwierząt. Czynią to sami prawodawcy w przywołanych aktach, np. w preambułach zarówno konwencji, jak i rozporządzenia 1099/2009. Co pewien czas temat uboju zwierząt i związane z nim kontrowersje pojawiają się w debacie publicznej. Ma to miejsce zwłaszcza wtedy, gdy podczas uśmiercania zwierząt dochodzi do nadużyć, a nawet znęcania się nad nimis

Podjęcie tematu regulacji prawnej ochrony dobrostanu zwierząt gospodarskich podczas ich uboju uzasadniają względy społeczno-gospodarcze i praktyczne. Pozyskiwanie produktów pochodzenia zwierzęcego ma strategiczne znaczenie dla gospodarki, ponieważ w naszym społeczeństwie wciąż dominuje tradycyjny model odżywiania. Wobec tego dokonywanie uboju zwierząt gospodarskich jest nieuniknione. Mimo że zwierzęta gospodarskie traktowane są użytkowo, to prawodawca dba o to, aby ich ubój nie łączył się z niepotrzebnym bólem i cierpieniem, był jak najbardziej humanitarny. Uśmiercanie zwierząt powinno więc odbywać się w atmosferze poszanowania ich jako istot żyjących, zdolnych do odczuwania cierpienia ${ }^{6}$.

Nie bez znaczenia pozostaje też aspekt praktyczny podjętego problemu badawczego. W ostatnich latach obserwuje się bowiem tendencję do wprowadzania modyfikacji w regulacjach ochrony zwierząt i tym samym zwiększania jej zakresu. Zmiany te są związane z rozwojem idei ochrony zwierząt. Sytuacja ta budzi wątpliwości przy dokonywaniu wykładni przepisów regulujących ochronę zwierząt, w tym możliwości ich uśmiercania. Do uzyskania klarowności w tej materii konieczne są zatem kolejne opracowania naukowe o charakterze prawniczym.

Głównym celem niniejszego artykułu jest odpowiedź na pytanie, w jaki sposób przejawia się ochrona dobrostanu zwierząt gospodarskich w momencie dokonywania ich uboju. Do zbadania tego zagadnienia niezbędna jest analiza europejskich i krajowych aktów prawnych.

2. Za właściwym postępowaniem ze zwierzętami w trakcie uboju, zgodnym z zasadą dobrostanu, przemawiają nie tylko przesłanki etyczne. W lite-

${ }^{4}$ Rozporządzenie Rady (WE) nr 1099/2009 z 24 września 2009 r. w sprawie ochrony zwierząt podczas ich uśmiercania (Dz. Urz. UE L z 2009 r., nr 303, poz. 1, dalej: rozporządzenie 1099/2009).

${ }^{5}$ Na przykład w 2021 r. ujawniono, że w ubojni w Witkowie dochodziło do znęcania się nad zwierzętami przeznaczonymi do uboju, co poruszyło opinię publiczną. Zob. K. Kojzar, ,, To nie sa zwierzęta wystawowe”. Co zdarzyło się w ubojni w Witkowie?, https://oko.press/to-nie-sa-zwierzeta-wystawowe-co-sie-zdarzylo-w-ubojni-w-witkowie-rzeznia-odc-1/ [dostęp: 12.09.2021].

${ }^{6}$ Zgodnie z art. 1 ust. 1 u.o.z. 
raturze wskazuje się, że poprawia to jakość pozyskanego mięsa ${ }^{7}$, pozytywnie wpływa na podejście konsumentów ${ }^{8}$, a także na bezpieczeństwo personelu ubojni ${ }^{9}$.

Niemożliwe jest takie dokonanie uboju zwierzęcia, aby nie doświadczyło ono w ogóle strachu, stresu, bólu i cierpienia. Zauważył to zarówno prawodawca w preambule rozporządzenia 1099/2009, jak i przedstawiciele nauki ${ }^{10}$. Mimo to ochronę zwierzą $\mathrm{w}$ momencie ich uśmiercania rozpatruje się w kontekście zasad dobrostanu zwierząt i ich humanitarnej ochrony, chociaż sam akt zabicia zwierzęcia jest powodem ogromnego cierpienia. W preambule rozporządzenia 1099/2009 opisano sam ubój i czynności z nim związane. Poruszono kwestię dobrostanu zwierząt w odniesieniu do głównych systemów ogłuszania i uśmiercania, a także uwzględniania dobrostanu zwierząt już na etapie planowania i budowy rzeźni. Ponadto stwierdzono, że w większości przypadków zwierzęta mogą być uśmiercone z poszanowaniem ich dobrostanu.

Ustawodawca polski w art. 33 ust. 1a u.o.z. wprowadził nakaz uśmiercania zwierząt wyłącznie w sposób humanitarny, który polega na minimalizowaniu zadawanego cierpienia fizycznego i psychicznego. Rodzi się wobec tego pytanie, jaka jest relacja tego przepisu do art. 5 u.o.z., który wprowadza obowiązek humanitarnego traktowania każdego zwierzęcia, a także do art. 4 pkt 2 u.o.z., który definiuje humanitarne traktowanie zwierząt jako traktowanie uwzględniające potrzeby zwierzęcia i zapewniające mu opiekę i ochronę. Trudno uznać, że moment uśmiercenia zwierzęcia zawiera się w ramach rozumianej w ten sposób zasady humanitaryzmu w relacjach człowieka ze zwierzętami. Wojciech Radecki proponuje uznać, że art. 5 u.o.z. odnosi się do zwierząt żywych i nieprzeznaczonych do uśmiercenia, a do tych, które z jakiegoś powodu muszą zostać uśmiercone, znajduje zastosowanie art. 33 ust. 1a u.o.z. ${ }^{11}$ Oznacza to, że sytuacja prawna poszczególnych grup zwierząt jest różna ${ }^{12}$, a tym samym stopień ich ochrony niejednolity. Czynnikiem różnicującym będzie decyzja uznania zwierzęcia za przeznaczone do uśmiercenia lub nie. W przypadku zwierząt gospodarskich przeznaczenie to wynika najczęściej ze sposobu wykorzystywania ich przez człowieka.

7 Szerzej: A. Cartoni Mancinelli, A. Dal Bosco, S. Mattioli, D. Ranucci, C. Castellini, Mobile poultry processing unit as a resource for small poultry farms: Planning and economic efficiency, animal welfare, meat quality and sanitary implications, „Animals” 2018, nr 8(12), s. 229 i n.

${ }^{8}$ Szerzej: M. Gębska, B. Gołębiewska, A. Grontkowska, Dobrostan zwierząt gospodarskich. Od teorii do praktyki, Warszawa 2018, s. 21-29.

${ }_{9}$ Szerzej: S. Mroczkowski, A. Frieske, Regulacje użytkowania zwierząt, Bydgoszcz 2016, s. $127 \mathrm{i} \mathrm{n}$.

${ }^{10}$ Ibidem.

${ }^{11}$ Szerzej: W. Radecki, Ustawy o ochronie zwierzat. Komentarz, Warszawa 2015, s. 165 i n.

${ }_{12}$ Szerzej: J. Goździewicz-Biechońska, E. Jachnik, Legal Status of the Animal as a Determinant of Its Humanitarian Protection, „Studia Iuridica Lublinensia” 2021, nr 3(30), s. 67-79. 
Zarówno prawodawca polski, jak i europejski wyróżniają pewne poziomy ochrony dobrostanu oraz humanitarnego traktowania zwierząt, zakładają ich stopniowalność. Wówczas nie rozpatruje się tych wartości w sposób bezkompromisowy i prosty, uznający tylko dwie możliwości: zastosowania ich w danym przypadku lub nie. Rozważa się raczej stopień ich realizacji. Widać to m.in. w kontekście uśmiercania zwierząt. Zwierzęta, które mają zostać uśmiercone, nadal podlegają ochronie prawnej, która przejawia się w humanitarnym traktowaniu oraz ochronie ich dobrostanu, mimo że uśmiercenie ich samo w sobie jest krzywdą. Gdyby uznać, że skoro akt ten jest tak wielką szkodą wyrządzoną zwierzęciu, to nie można mówić o jego prawnej ochronie, humanitarnym traktowaniu ani ochronie jego dobrostanu, mogłoby to otworzyć drogę do nieporozumień i nadużyć. Taka konstatacja mogłaby prowadzić do uznania, że zwierzętom, które mają zostać uśmiercone, prawna ochrona nie przysługuje, dlatego można traktować je przedmiotowo.

Warto zauważyć, że próby tłumaczenia sprawców przestępstw znęcania się nad zwierzętami, które mają zostać poddane ubojowi, iż w takich okolicznościach pełna ochrona prawna im się nie należy, pojawiają się, odkąd zostały wprowadzone regulacje dotyczące uśmiercania zwierząt gospodarskich. Taka argumentacja była jednak zawsze potępiana przez sądy. Jako przykład można przywołać wyrok Sądu Najwyższego z 2 maja 1935 r. ${ }^{13}$ Oskarżony w tej sprawie został skazany za znęcanie się nad cielęciem przed dokonaniem jego uboju ${ }^{14}$. Złożył następnie kasację, podnosząc, że przepisy rozporządzenia o ochronie zwierząt ${ }^{15}$ dotyczą zwierząt, których przeznaczeniem nie jest ubój. Sąd Najwyższy zdecydowanie odrzucił taką argumentację, wskazując, że rozporządzenie o ochronie zwierząt nie rozróżnia kategorii zwierząt przeznaczonych na ubój oraz tych, które mają nadal żyć. Znęcanie się oznacza wszelkie zadawanie cierpień, również zwierzętom przeznaczonym do uboju, bez ważnej, słusznej i prawnie dozwolonej potrzeby.

Europejski Urząd ds. Bezpieczeństwa Żywności (EFSA) przyjął wiele opinii na temat dobrostanu w odniesieniu do głównych systemów ogłuszania i uśmiercania niektórych gatunków zwierzą ${ }^{16}$. Na konieczność rozpatrywa-

13 Wyrok SN z 2 maja 1935 r., sygn. akt: II K 375/35, OSN(K) 1936/1/2, LEX nr 368065.

${ }^{14} \mathrm{~W}$ niniejszej sprawie oskarżony chciał dokonać uboju cielęcia w celu pozyskania żywności. Przed uśmierceniem jednak związał nogi zwierzęciu, powiesił je głową w dół na haku i oddalił się na dłuższy czas, pozostawiając je i skazując na niepotrzebne cierpienie. Ryk cielęcia ściągnął na miejsce ludzi, w tym lekarza weterynarii, który nakazał zdjęcie zwierzęcia z haka. Czyn oskarżonego został uznany za znęcanie się ze szczególnym okrucieństwem, a sam oskarżony - skazany na mocy wyroku Sądu Okręgowego w Stanisławowie z 23 listopada 1934 r.

15 Rozporządzenie Prezydenta Rzeczypospolitej z 22 marca 1928 r. o ochronie zwierząt (t.j. Dz. U. z 1932 r., nr 42, poz. 417).

${ }_{16}$ Wydane dotąd opinie można znaleźć pod adresem: https://www.efsa.europa.eu/en/topics/ topic/animal-welfare-slaughter [dostęp: 14.06.2021]. 
nia kwestii uboju zwierząt gospodarskich przez pryzmat zasady dobrostanu wskazują także przedstawiciele nauki ${ }^{17}$. Opinie te zostały wydane odrębnie dla bydła, trzody chlewnej, owiec, kóz, drobiu i królików z uwzględnieniem ich potrzeb gatunkowych. EFSA, mając na uwadze specyficzne wymagania, opublikowała także osobną opinię na temat uśmiercania zwierząt ciężarnych. Urząd, wydając regularnie tego rodzaju dokumenty, ma na względzie rozwój wiedzy i technologii dokonywania uboju. Na mocy art. 4 ust. 2 i 3 na podstawie tych opinii możliwe jest wprowadzanie zmian do załącznika I rozporządzenia 1099/2009, który określa dopuszczalne metody ogłuszania.

Artykuł 1 rozporządzenia 1099/2009 reguluje kwestie związane z uśmiercaniem zwierząt hodowanych lub utrzymywanych w celu pozyskiwania produktów pochodzenia zwierzęcego, takich jak mięso, skóry, futra. Przepis ten dopuszcza także zastosowanie niektórych postanowień rozporządzenia do uśmiercenia zwierząt z konieczności, czyli poza rzeźnią, lub z pominięciem niektórych przepisów, gdy wymaga tego sytuacja, w której w innym przypadku zagrożone byłoby zdrowie lub bezpieczeństwo ludzi. W art. 3 ust. 3 prawodawca wyraźnie wskazał, że rozporządzenie to nie ma zastosowania do przypadków uśmiercania zwierząt podczas eksperymentów naukowych, polowań lub rekreacyjnego łowienia ryb, podczas imprez kulturalnych i sportowych, a także do uboju drobiu, królików i zajęcy dokonywanego przez ich właściciela na użytek własny. Głównym celem rozporządzenia 1099/2009 jest zatem regulacja uboju zwierząt rozumianego jako końcowy etap procesu produkcji rolnej.

Prawodawca w rozporządzeniu 1099/2009 rozróżnia pojęcia uśmiercania oraz uboju zwierząt. Zgodnie z art. 2 lit. a uśmiercanie oznacza każdy celowo wywołany ciąg czynności, który powoduje śmierć zwierzęcia. Natomiast zgodnie $\mathrm{z}$ art. 2 lit. j ubój jest kwalifikowaną postacią uśmiercenia, ukierunkowaną na pozyskanie produktów przeznaczonych do spożycia przez ludzi. W związku z rozróżnieniem przez prawodawcę tych pojęć należy uznać, że przepisy dotyczące uboju zwierząt będą stanowiły lex specialis do przepisów dotyczących uśmiercania zwierząt, traktowanych jako lex generalis. Ponadto ubój przemysłowy należy rozumieć jako ubój, który odbywa się w specjalnie do tego przeznaczonych rzeźniach ${ }^{18}$ lub ubojniach ${ }^{19}$. Muszą one spełniać

17 Szerzej: R. Urban-Chmiel, Kryteria dobrostanu zwierząt podczas uboju w świetle dyrektywy nr 1099/2009 obowiazującej od 1 stycznia 2013 r., „Życie Weterynaryjne” 2013, nr 2(88), s. 144-146.

${ }_{18}$ Rozumianych zgodnie $\mathrm{z}$ definicją zawartą $\mathrm{w}$ załączniku I do rozporządzenia (WE) nr 853/2004 Parlamentu Europejskiego i Rady z 29 kwietnia 2004 r. ustanawiającego szczególne przepisy dotyczące higieny w odniesieniu do żywności pochodzenia zwierzęcego (Dz. Urz. UE L 2004, nr 139, poz. 55) jako zakład dokonujący uboju i patroszenia zwierząt, których mięso jest przeznaczone do spożycia przez ludzi.

19 Rozumianych zgodnie z definicją zawartą w art. 4 pkt 13 u.o.z. jako każdy zakład pozostający pod państwową kontrolą sanitarną i weterynaryjną, przeznaczony do wykonywania uboju zwierząt. 
wiele określonych prawem wymogów, przede wszystkim o charakterze sanitarnym i technicznym. Co istotne, ubój przemysłowy dokonywany jest na zdrowych zwierzętach pod kontrolą lekarza weterynarii ${ }^{20}$.

W rozporządzeniu 1099/2009 prawodawca unijny uregulował kwestie związane z minimalizowaniem bólu i cierpienia oraz ogłuszaniem zwierząt w związku z wykonywanymi czynnościami ubojowymi. W art. 3 ust. 1 wyrażono ogólną zasadę głoszącą, że podczas uśmiercania i działań związanych $\mathrm{z}$ uśmiercaniem zwierzętom oszczędza się wszelkiego niepotrzebnego bólu, niepokoju lub cierpienia. Zgodnie z ust. 2 należy im zapewnić fizyczny komfort i ochronę, szczególnie przez utrzymywanie ich w czystości i w odpowiednich warunkach cieplnych oraz zapobieganie upadkom lub potknięciom, ochronę przed urazami, obchodzenie się z nimi i przetrzymywanie ich w sposób uwzględniający ich zwykłe zachowanie, warunki, w których nie wykazują oznak niepotrzebnego bólu lub strachu ani nietypowego zachowania, warunki, w których nie cierpią z powodu przedłużającego się braku pokarmu lub wody, a także warunki, w których wyeliminowany jest niepotrzebny kontakt z innymi zwierzętami, który mógłby negatywnie wpłynąć na ich dobrostan.

Jedną z głównych zasad wprowadzonych przez rozporządzenie 1099/2009 jest ogłuszenie zwierzęcia przed uśmierceniem. Zgodnie $z$ definicją zawartą w art. 2 lit. f ogłuszenie oznacza każdy celowo wywołany ciąg czynności, który bezboleśnie powoduje utratę przytomności i wrażliwości na bodźce, w tym każdy szereg czynności powodujący natychmiastową śmierć. Natomiast polski prawodawca w art. 4 pkt 6 u.o.z. zdefiniował ogłuszenie zwierzęcia jako metodę profesjonalnego całkowitego wyłączenia świadomości zwierzęcia, trwającego aż do jego śmierci. Obowiązek ogłuszenia zwierzęcia przed dokonaniem uboju wprowadza art. 4 rozporządzenia 1099/2009. Metody oraz szczegółowe wymogi ogłuszania zawiera załącznik I do omawianego aktu. Stan nieprzytomności i niewrażliwości na bodźce należy utrzymywać do momentu śmierci zwierzęcia. Konieczność ogłuszenia zwierzęcia przed jego uśmierceniem wprowadza także art. 34 ust. 1 i 3 u.o.z.

Właściwe ogłuszenie zwierzęcia przed dokonaniem uboju ma na celu czynić zadość zasadzie dobrostanu zwierząt ${ }^{21}$. Prawodawca stwierdził także w preambule, że jeśli zawiodą procedury ogłuszania, zwierzęta są narażone

${ }^{20}$ S. Mroczkowski, A. Frieske, Prawna ochrona zwierzat gospodarskich, Bydgoszcz 2015, s. 89 i n.

${ }^{21}$ Szerzej: M. Girasole, C. Chirollo, M. Ceruso, L. Vollano, A. Chianese, M. L. Cortesi, Optimization of stunning electrical parameters to improve animal welfare in a poultry slaughterhouse, „Italian Journal of Food Safety” 2015, nr 4(3), s. 175 i n. 
na cierpienie. Zgodnie ze stanowiskiem nauk przyrodniczych i medycznych ubój zwierzęcia bez wcześniejszego ogłuszenia naraża je na silny ból i stres ${ }^{22}$. Badanie fal mózgowych ogłuszonych zwierząt wykazało, że zdecydowanie powoduje ono niewrażliwość na czynniki wyzwalające ból, cierpienie i stres ${ }^{23}$. Przedstawiciele tych nauk wskazują więc, że praktyka pozbawienia zwierzęcia przytomności jest konieczna ze względu na jego dobrostan. Lekarze weterynarii pozostają natomiast zgodni, że ubój bez ogłuszania powoduje zbędny, a możliwy do uniknięcia ból i cierpienie. Praktykę tę oceniają jako niedopuszczalną, a skuteczne ogłuszenie zwierząt przed ubojem jako priorytetowe ${ }^{24}$.

Również wskazane przez prawodawcę polskiego i unijnego w przytoczonych wcześniej legalnych definicjach ogłuszania cechy tego zabiegu: bezbolesność i profesjonalność sprzyjają zasadzie dobrostanu zwierząt. Z jednej strony samo działanie mające na celu minimalizowanie bólu i cierpienia zwierząt nie może powodować tych uciążliwości. Dlatego personel dokonujący ogłuszania powinien być w pełni profesjonalny, a więc dysponować odpowiednią wiedzą na temat tej procedury. $Z$ drugiej strony, zgodnie $\mathrm{z}$ art. 5 ust. 1 rozporządzenia 1099/2009, należy dla pewności przeprowadzić kontrolę, czy ogłuszenie zwierzęcia przyniosło oczekiwany efekt. Jeśli nie, konieczne jest wówczas wdrożenie odpowiednich, opracowanych wcześniej procedur.

3. Nie ulega wątpliwości, że mimo podejmowania działań mających na celu najbardziej humanitarne sposoby obchodzenia się ze zwierzętami przeznaczonymi do uboju sam ten akt zawsze będzie stanowił przejaw okrucieństwa. Wszelkie czynności podejmowane od momentu dotarcia zwierząt do ubojni i ich rozładunku muszą być wykonywane w duchu poszanowania zasady dobrostanu. Zaniedbania $\mathrm{w}$ tym zakresie mogą zniweczyć założenia prawnej ochrony zwierząt, które mają na celu zagwarantowanie zwierzętom opieki i ochrony jako istotom żyjącym i zdolnym do odczuwania cierpienia. Unia Europejska jest samowystarczalna, jeśli chodzi o produkcję wołowiny i mięsa drobiowego, a Polska znajduje się w czołówce państw członkowskich

${ }^{22}$ Szerzej: M. Miele, Killing Animals for Food: How Science, Religion and Technologies Affect the Public Debate About Religious Slaughter, „Food Ethics” 2016, t. 1, s. 56.

${ }_{23}$ P. McNulty, P.M. Grace, Encyclopedia of life support systems. Agricultural mechanization and automation, t. 2, Oxford 2009, s. $370 \mathrm{i} \mathrm{n.}$

${ }^{24}$ Humane Slaughter of Animals - Position Statement Ottawa, Ottawa, ON 2016, https://www. canadianveterinarians.net/documents/humane-slaughter-of-animals-position-statement [dostęp: 14.06.2021]; F. Nind, O. Bro-Jorgensen, A. Meisser, A.W. Udo, B. Zemljic, Slaughter of Animals without Prior Stunning, FVE Position Paper, Brussels, 15 września 2017 r., https://www.veterinaire. fr/fileadmin/user_upload/documents/outils-et-services/Index_juridique/Premiere_lettre_de_M_a_Z/ Religious_slaughter_and_food_chain.pdf [dostęp: 14.06.2021]. 
produkujących największe ilości tego typu mięsa ${ }^{25}$. Można więc przyjąć, że ubój zwierząt gospodarskich jest zjawiskiem szeroko zakrojonym.

Ogromne znaczenie dla zachowania dobrostanu zwierząt ma postawa personelu rzeźni ${ }^{26}$. Dlatego zgodnie z art. 7 ust. 1 rozporządzenia 1099/2009 uśmiercanie i działania związane z uśmiercaniem przeprowadzane są wyłącznie przez osoby posiadające odpowiednie kwalifikacje, aby wykonywać te czynności, nie powodując u zwierząt niepotrzebnego bólu, niepokoju lub cierpienia. Art. 7 ust. 2 zawiera katalog czynności wykonywanych przy zwierzętach w ubojniach, które mogą wykonywać wyłącznie osoby posiadające stosowne świadectwo kwalifikacji. Do tych czynności zalicza się: obchodzenie się ze zwierzętami i opieka nad nimi przed ich skrępowaniem, krępowanie zwierząt w celu ogłuszenia lub uśmiercenia, ogłuszanie zwierząt, ocena skuteczności ogłuszenia, pętanie lub podwieszanie żywych zwierząt, wykrwawianie żywych zwierząt oraz ubój religijny. Sposób uzyskania świadectwa kwalifikacji wyznacza art. 21 rozporządzenia 1099/2009.

Spośród odpowiednio wykwalifikowanego personelu podmiot prowadzący rzeźnię jest zobowiązany, na podstawie art. 17 rozporządzenia 1099/2009, wyznaczyć pracownika, który będzie odpowiedzialny za dobrostan zwierząt. Do jego zadań należy zapewnienie właściwej realizacji przepisów rozporządzenia 1099/2009. Ma on składać sprawozdanie z wykonywanych zadań podmiotowi gospodarczemu, któremu podlega. Musi posiadać kompetencje do wymagania od personelu rzeźni, aby podejmował wszelkie środki naprawcze niezbędne do zapewnienia warunków określonych przez rozporządzenie 1099/2009. Powinien też prowadzić rejestr działań, które zostały podjęte, aby zapewnić odpowiedni dobrostan zwierząt przebywających na terenie rzeźni.

Zapewnienie odpowiedniego dobrostanu zwierząt w rzeźniach wymaga właściwego planowania. Dlatego konieczne jest uwzględnienie ochrony dobrostanu już na etapie projektowania budynku i wyposażenia rzeźni. Obowiązek taki wynika z art. 14 ust. 1 rozporządzenia 1099/2009. Rozplanowanie, budowa i wyposażenie rzeźni muszą spełniać wymogi określone w załączniku II do rozporządzenia 1099/2009. Dotyczą one magazynów, w których przetrzymuje się zwierzęta, obiektów i urządzeń przeznaczonych do krępowania, a także urządzeń do ogłuszania zwierząt. Zgodnie

${ }^{25}$ R. Mroczek, Ubój religijny zwierząt rzeźnych w Polsce, „Zagadnienia Ekonomiki Rolnej” 2021, nr 1(366), s. 91-112; idem, Analiza wptywu regulacji zwiazanych z ,wygaszaniem” branży futrzarskiej w Polsce (m.in. w zakresie zagospodarowania przez niq odpadów poubojowych) $n p$. $w$ zakresie ewentualnego wzrostu cen mięsa $i$ wędlin czy następstw likwidacji uboju rytualnego - dla rolnictwa w Polsce i innych branż (m.in. spadku poziomu rentowności poszczególnych dziatów gospodarki), ekspertyza z 5.10.2020 r., https://www.senat.gov.pl/download/gfx/senat/pl/ senatinicjatywypliki/8575/4/209_ekspertyzaks.pdf [dostęp: 31.08.2021].

${ }^{26}$ P. McNulty, P.M. Grace, Encyclopedia of life support systems..., s. 369 i n. 
z art. 14 ust. 2 podmioty prowadzące rzeźnie są zaś zobowiązane do prowadzenia dokumentacji dotyczącej wydajności danego obiektu.

Zgodnie z art. 15 ust. 1 rozporządzenia 1099/2009 podmioty gospodarcze prowadzące rzeźnie przestrzegają zasad operacyjnych wyszczególnionych w załączniku III. Składają się na nie reguły postępowania ze zwierzętami w trakcie ich przywozu, przemieszczania oraz niezbędnej opieki. Ważną zasadą jest natychmiastowy rozładunek zwierząt oraz niezwłoczne poddanie ich ubojowi. Każdorazowo należy ocenić dobrostan poszczególnych zwierząt przybyłych do ubojni. Załącznik określa także sposoby obchodzenia się z kontenerami, w których podróżowały zwierzęta i w których nadal one przebywają, traktowanie zwierząt $\mathrm{w}$ okresie laktacji oraz samic w połogu, a także niezbędną opiekę, obejmującą m.in. dostarczanie wody pitnej i pożywienia, zapewnienie godnych warunków na czas oczekiwania, dojenie zwierząt mlecznych etc.

W załączniku III do rozporządzenia 1099/2009 wyszczególnione są także formy postępowania ze zwierzętami przeznaczonymi do uboju, które są bezwzględnie zakazane, a które z pewnością powodowałyby niepotrzebny dodatkowy ból i cierpienie. Należą do nich uderzanie lub kopanie zwierząt, stosowanie nacisku na jakąkolwiek, szczególnie wrażliwą część ciała w sposób powodujący niepotrzebny ból lub cierpienie, podnoszenie lub ciągnięcie zwierząt za głowę, uszy, rogi, nogi, ogon lub sierść, podnoszenie zwierząt za nogi ${ }^{27}$, stosowanie poganiaczy lub innych narzędzi z zaostrzonymi końcami, wykręcanie, zgniatanie lub łamanie ogonów zwierząt lub chwytanie oczu jakiegokolwiek zwierzęcia. Należy także ograniczać używanie przyrządów powodujących wstrząsy elektryczne.

4. Szczególną formą uśmiercania zwierząt jest ubój na użytek własny, zwany także ubojem domowym. Rozporządzenie 1099/2009 na mocy art. 1 ust. 3 lit. b nie reguluje uboju drobiu, królików i zajęcy ubitych na potrzeby konsumpcji domowej. Zgodnie z motywem 17 preambuły tego aktu takie wyłączenie uzasadnione jest dwoma względami. Po pierwsze, ubój tych zwierząt na potrzeby konsumpcji domowej nie jest przeprowadzany w wymiarze, który mógłby mieć wpływ na konkurencyjność ubojni komercyjnych. Po drugie, niezbędne kroki, które organy władzy publicznej musiałyby podjąć w celu wykrycia i kontroli tych działań, byłyby nieproporcjonalne do potencjalnych problemów do rozwiązania. O ile można zgodzić się, że nie sposób wykryć i skutecznie kontrolować dozwolonego uboju domowego tych zwierząt, o tyle należy spodziewać się, że występują przy nim analogiczne problemy z zapewnieniem dobrostanu zwierząt, np. przy skutecznym

27 Zakaz nie dotyczy jednak drobiu, królików i zajęcy. 
ogłuszaniu czy przy monitorowanych przez odpowiednie służby i inspekcje ubojach komercyjnych i religijnych. Niemniej ze względu na wspomniane problemy ubój ten obecnie musi zostać poza kontrolą władzy publicznej, a kwestie dobrostanu zwierząt - poza zainteresowaniem prawnym. Jest to jednak sprawa wymagająca odpowiedniej edukacji społeczeństwa w zakresie ochrony dobrostanu i humanitarnego traktowania tych zwierząt.

Pod pojęciem ,ubój domowy” rozumie się ubój przeprowadzony w gospodarstwie właściciela. Wszelkich czynności z nim związanych dokonuje się ręcznie, a pozyskane surowce i produkty przeznaczone są na własny użytek ${ }^{28}$. Zgodnie z art. 10 rozporządzenia 1099/2009 do uboju zwierząt innych niż drób, króliki i zające oraz do czynności związanych z uśmiercaniem wykonywanych poza rzeźnią przez właściciela tych zwierząt lub osobę działającą na odpowiedzialność i pod nadzorem właściciela do celów konsumpcji domowej mają zastosowanie wyłącznie takie wymogi, jak oszczędzenie im niepotrzebnego bólu, niepokoju lub cierpienia, uprzednie ogłuszenie zwierząt, a także dokonanie uboju przez wykwalifikowanego ubojowca. Ponadto w przypadku uboju poza rzeźnią na własny użytek zwierząt innych niż drób, króliki i zające, świnie, owce i kozy nie stosuje się zabronionych, okrutnych metod krępowania określonych w art. 15 ust. 3 rozporządzenia 1099/2009, a także dokonuje się tzw. ogłuszania prostego określonego w załączniku III do analizowanego rozporządzenia.

Zgodnie z art. 5 pkt 1a ustawy o produktach pochodzenia zwierzęcego ${ }^{29}$ ubój na użytek własny oznacza pozyskiwanie mięsa na własne potrzeby. Nie jest zatem możliwa sprzedaż pozyskanych w ten sposób produktów pochodzenia zwierzęcego. Muszą one spełniać wymogi zarówno zawarte w u.p.p.z., jak i innych aktach z zakresu prawa żywnościowego czy prawnej ochrony zwierząt. Jednym $\mathrm{z}$ ważniejszych aktów regulujących tę materię jest wydane na podstawie art. 11a ust. 2 u.p.p.z. rozporządzenie Ministra Rolnictwa i Rozwoju Wsi z 21 października 2010 r. w sprawie wymagań weterynaryjnych przy produkcji mięsa przeznaczonego na użytek własny ${ }^{30}$. Nakłada ono obowiązek zgłoszenia planowanego uboju właściwemu powiatowemu lekarzowi weterynarii przynajmniej 24 godziny wcześniej, co daje możliwość kontroli dokonania uboju w odpowiedni sposób, m.in. z poszanowaniem przepisów dotyczących ochrony dobrostanu zwierząt.

${ }^{28}$ S. Mroczkowski, A. Frieske, Prawna ochrona ..., s. 89 i n.

${ }^{29}$ Ustawa z 16 grudnia 2005 r. o produktach pochodzenia zwierzęcego (t.j. Dz. U. z 2020 r., nr 10, poz. 09, dalej: u.p.p.z.).

${ }^{30}$ Rozporządzenie Ministra Rolnictwa i Rozwoju Wsi z 21 października 2010 r. w sprawie wymagań weterynaryjnych przy produkcji mięsa przeznaczonego na użytek własny (t.j. Dz. U. z 2016 r., poz. 885). 
5. Mimo że ogólna zasada wprowadzona art. 4 ust. 1 rozporządzenia 1099/2009 głosi, iż ogłuszenie jest warunkiem wywołania stanu braku przytomności i wrażliwości na bodźce przed lub w trakcie uśmiercania zwierzęcia, to prawodawca przewidział wyjątek od niej w ust. 4 tego artykułu, który przewiduje możliwość dokonania uboju rytualnego bez ogłuszenia, ale tylko gdy ubój dokonywany jest w rzeźniach. W motywie 43 preambuły tego rozporządzenia zaznaczono natomiast, że ubój bez uprzedniego ogłuszenia wymaga dokładnego podcięcia gardła zwierzęcia ostrym nożem w celu zminimalizowania cierpienia. Wyjątek ten wprowadzono ze względu na potrzeby niektórych wspólnot religijnych do przeprowadzania takiego uboju, który traktowany jest jako forma sprawowania kultu. Możliwość praktykowania go zapewnia zasada wolności religijnej ${ }^{31}$.

Ubój rytualny nie mieści się $\mathrm{w}$ granicach zasady dobrostanu zwierząt. Ten sposób uśmiercenia zwierzęcia nie realizuje głównych jej postulatów, z założenia dopuszcza uczucie silnego dyskomfortu i stresu, a także bólu, ponieważ wyłącza możliwości uprzedniego ogłuszenia, co związane jest $\mathrm{z}$ udziałem pełnej świadomości zwierzęcia w trakcie umierania. Także na mocy art. 1 ust. 2 Europejskiej konwencji o ochronie zwierząt przeznaczonych do uboju zasadą jest, że uśmiercenie zwierzęcia następuje po jego ogłuszeniu, która to czynność ma oszczędzić zwierzęciu, w każdym przypadku, cierpień, których można uniknąć. Konwencja ta zezwala jednak w art. 17 na wyjątkowe sytuacje, w których ubój może zostać dokonany przy pełnej świadomości zwierzęcia, m.in. ze względu na swobodę praktykowania religii.

W kontekście uboju rytualnego i ochrony dobrostanu zwierząt warto wspomnieć o pewnej alternatywie. Zgodnie z definicją zawartą w rozporządzeniu 1099/2009 niektóre formy ogłuszania dopuszczone przez prawodawcę mogą wywołać także śmierć. Takie uregulowanie tej kwestii jest o tyle istotne, że niektóre grupy religijne dopuszczają ubój rytualny po uprzednim ogłuszeniu zwierzęcia, jeśli można zagwarantować, że umarło ono w wyniku rytuału, a nie ogłuszenia. Innymi słowy, dopuszczają ogłuszenie zwierzęcia, gdy jest ono odwracalne. Otwiera to możliwość dopuszczenia uboju religijnego poprzedzonego ogłuszeniem, które samo w sobie nie powoduje śmierci zwierzęcia. Regulacje tego typu wprowadziła Belgia, co spowodowało wniesienie skargi do Trybunału Sprawiedliwości przez związki wyznawców islamu działające na terytorium tego kraju ${ }^{32}$. Sąd orzekł, że takie rozwiązanie prawne nie jest sprzeczne z postanowieniami rozporządzenia 1099/2009, które co prawda dopuszcza ubój bez ogłuszania, ale pozostawia

31 Szerzej o prawnych aspektach uboju rytualnego: E. Jachnik, Prawne aspekty uboju rytualnego, „Przegląd Prawa Rolnego” 2016, nr 1, s. 177 i n.

32 Wyrok TK z 17 grudnia 2020 r., C-336/19, LEX nr 3095387. 
swobodę państwom członkowskim do wprowadzenia wyższego standardu ochrony zwierząt. Stwierdził też, że skoro możliwe jest całkowite zakazanie uboju rytualnego, to państwo członkowskie może dopuścić takie praktyki w określonych warunkach.

6. Na podstawie obowiązującej regulacji można wysnuć wniosek, że ogłuszenie zwierzęcia przed dokonaniem uboju realizuje zasadę dobrostanu i jest motywowane chęcią zapewnienia godnych, w miarę możliwości humanitarnych, warunków uśmiercenia zwierzęcia. W takim momencie konieczne jest zatem pozbawienie zwierzęcia świadomości, co potwierdzają przytoczone w niniejszym artykule stanowiska przedstawicieli świata nauki. Sięganie do opracowań nauk przyrodniczych przy pracach legislacyjnych nad zagadnieniem uboju rytualnego jest oczywiste i ze wszech miar konieczne dla właściwego rozstrzygnięcia problematycznych kwestii.

Nie jest możliwe dokonanie uboju w taki sposób, aby uniknąć stresu czy bólu zwierzęcia. W samym akcie uśmiercenia zawiera się bowiem dopuszczenie do zadania cierpienia. Dlatego należy przyjąć, że realizacja zasady ochrony dobrostanu jest stopniowalna. Można mówić o zapewnieniu wysokiego stopnia dobrostanu zwierząt, co jest np. jednym z założeń rolnictwa ekologicznego. Natomiast w kontekście uboju należy przyjąć, że powinno się zapewnić przynajmniej minimalny poziom dobrostanu. Ma temu służyć przede wszystkim uniewrażliwienie zwierzęcia na bodźce.

Dokonywanie uboju zwierząt bez uprzedniego ogłuszenia stanowi świadome uchybienie zasadzie ochrony dobrostanu. Nie jest także rekomendowane w świetle obecnej wiedzy przez lekarzy weterynarii. Prawodawstwo Unii Europejskiej i wielu państw członkowskich przewiduje jednak wyjątek dla uboju rytualnego, który zakłada uśmiercenie zwierzęcia bez uprzedniego pozbawienia go świadomości. Możliwość taka została wprowadzona ze względu na poszanowanie wolności religijnej. Wśród wyznawców religii, dla których przewidziano takie odstępstwo, nie panuje jednak zgoda co do możliwości ogłuszania zwierząt przed ubojem. Istnieją grupy, które dopuszczają do uniewrażliwienia zwierzęcia na bodźce przed dokonaniem obrzędu uboju, jeśli sposób ten sam w sobie nie jest jednocześnie formą uśmiercenia. W świetle przepisów unijnych państwa członkowskie mają prawo zezwolić na ubój rytualny tylko w ograniczonym zakresie, tzn. właśnie po uprzednim ogłuszeniu, np. przez porażenie prądem.

Prawodawca wiąże kwestie odpowiedniego uboju zwierząt gospodarskich nie tylko z odpowiednią regulacją prawną, ale także z właściwą edukacją osób zajmujących się zawodowo ubojem, personelu rzeźni, rolników, a w szerszej perspektywie - całego społeczeństwa. Problemu edukacji wy- 
mienionych grup nie można lekceważyć, ponieważ dogłębne zrozumienie przez nie istoty oraz celów ochrony dobrostanu zwierząt pozwoli zapewnić zwierzętom humanitarne traktowanie w momencie śmierci. Ma to szczególne znaczenie w przypadku uboju dokonanego na własny użytek przez rolnika, ponieważ w tym przypadku prawo przewiduje ograniczone możliwości kontroli. Planowany ubój domowy należy zgłosić do właściwego powiatowego lekarza weterynarii, a niespełnienie tego warunku może prowadzić do nałożenia kary finansowej. Istnieje jednak ryzyko, że ubój zostanie dokonany bez wymaganego powiadomienia, a właściwe organy nie będą w posiadaniu informacji na ten temat.

\section{BIBLIOGRAFIA}

Cartoni Mancinelli A., Dal Bosco A., Mattioli S., Ranucci D., Castellini C. (2018), Mobile poultry processing unit as a resource for small poultry farms: planning and economic efficiency, animal welfare, meat quality and sanitary Implications, „Animals” nr 8(12).

Gabriel-Węglowski M. (2008), Przestępstwa przeciwko humanitarnej ochronie zwierząt, Torun.

Gębska M., Gołębiewska B., Grontkowska A. (2018), Dobrostan zwierząt gospodarskich. Od teorii do praktyki, Warszawa.

Girasole M., Chirollo C., Ceruso M., Vollano L., Chianese A., Cortesi M.L. (2015), Optimization of stunning electrical parameters to improve animal welfare in a poultry slaughterhouse, „Italian Journal of Food Safety” nr 4(3).

Goździewicz-Biechońska J., Jachnik E. (2021), Legal Status of the Animal as a Determinant of Its Humanitarian Protection, „Studia Iuridica Lublinenisia” nr 3(30).

Jachnik E. (2016), Prawne aspekty uboju rytualnego, „Przegląd Prawa Rolnego” nr 1(18).

Kojzar K., ,, To nie sa zwierzęta wystawowe”. Co zdarzyło się w ubojni w Witkowie?, https:// oko.press/to-nie-sa-zwierzeta-wystawowe-co-sie-zdarzylo-w-ubojni-w-witkowie-rzeznia-odc-1/ [dostęp: 12.09.2021].

McNulty P., Grace P.M. (2009), Encyclopedia of life support systems. Agricultural mechanization and automation, Oxford.

Miele M. (2016), Killing Animals for Food: How Science, Religion and Technologies Affect the Public Debate About Religious Slaughter, „Food Ethics” t. 1.

Mroczek R. (2020), Analiza wpływu regulacji związanych z ,wygaszaniem” branży futrzarskiej w Polsce (m.in. w zakresie zagospodarowania przez nia odpadów poubojowych) $n p$. w zakresie ewentualnego wzrostu cen mięsa $i$ wędlin czy następstw likwidacji uboju rytualnego - dla rolnictwa $w$ Polsce i innych branż (m.in. spadku poziomu rentowności poszczególnych działów gospodarki), ekspertyza, https://www.senat.gov.pl/download/ gfx/senat/pl/senatinicjatywypliki/8575/4/209_ekspertyzaks.pdf [dostęp: 31.08.2021].

Mroczek R. (2021), Ubój religijny zwierząt rzeźnych w Polsce, „Zagadnienia Ekonomiki Rolnej" nr 1(366).

Mroczkowski S., Frieske A. (2016), Regulacje użytkowania zwierząt, Bydgoszcz.

Nind F., Bro-Jorgensen O., Meisser A., Udo A.W., Zemljic B. (2017), Slaughter of Animals without Prior Stunning, FVE Position Paper, Brussels, https://www.veterinaire.fr/ 
fileadmin/user_upload/documents/outils-et-services/Index_juridique/Premiere_lettre_ de_M_a_Z/Religious_slaughter_and_food_chain.pdf [dostęp: 14.06.2021]. Radecki W. (2015), Ustawy o ochronie zwierząt. Komentarz, Warszawa.

Urban-Chmiel R. (2013), Kryteria dobrostanu zwierzą podczas uboju w świetle dyrektywy nr 1099/2009 obowiąujacej od 1 stycznia 2013 r., „Życie Weterynaryjne” nr 2(88).

\title{
LEGAL PROTECTION OF THE WELFARE OF FARMED ANIMALS DURING SLAUGHTER
}

\begin{abstract}
Summary
The main objective of this article is to determine the level of protection of the welfare of farmed animals at the time of slaughter. The analysis of international, European as well as national laws indicates a general assumption that the life of animals is a legally protected good. However, there are certain exceptions to this principle, one of the being the slaughter of farmed animals for the purpose of obtaining certain products of animal origin. Generally speaking, protection of farmed animals during slaughter is reduced to the protection of their welfare and assurance of their most humane treatment, if such is at all possible in a situation of killing. The main protective instrument provided for this is the obligation to stun the animals to effectively render them insensible to environmental stimuli. A derogation from this requirement is only envisaged for ritual slaughter. As can be seen, protection of animals at the time of killing, as well as the effective control of such a procedure, poses certain problems.
\end{abstract}

Keywords: animal welfare, livestock, slaughter of animals, stunning of animals

\section{LA TUTELA GIURIDICA DEL BENESSERE DEL BESTIAME DURANTE L'ABBATTIMENTO}

\section{Riassunto}

L'articolo si propone di rispondere alla domanda in quale modo si realizzi la tutela del benessere del bestiame al momento dell'abbattimento. L'analisi sia degli atti di diritto internazionale e europeo che di quelli di diritto nazionale permette di individuare un principio generale secondo il quale la vita degli animali è un bene giuridico protetto. Tuttavia, il legislatore ha previsto alcune eccezioni, tra le quali, vista la necessità di ottenere alcuni prodotti di origine animale, rientra l'abbattimento. La tutela del bestiame nel momento dell'uccisione si riduce a proteggere il loro benessere e ad assicurare loro un trattamento umano, ovviamente per quanto sia possibile viste le circostanze. Il principale strumento di tutela equivale all'obbligo di stordire gli animali, ovvero di renderli, nel modo più efficace, meno sensibili agli stimoli dell'ambiente circostante. La deroga è prevista solo in caso di abbattimento secondo riti religiosi. La tutela degli animali nel momento dell'uccisione, nonché un controllo effettivo di come ciò si svolge nella realtà pone certi problemi.

Parole chiave: benessere degli animali, bestiame, abbattimento degli animali, stordimento degli animali 